\title{
Quality in the pepper under different fertigation managements and levels of nitrogen and potassium ${ }^{1}$
}

\author{
Qualidade do pimentão sob manejos de fertirrigação e diferentes níveis de nitrogênio \\ e potássio
}

\author{
Francisco de Assis de Oliveira ${ }^{2 *}$, Sergio Nascimento Duarte ${ }^{3}$, José Francismar de Medeiros ${ }^{2}$, Edna Maria Mendes \\ Aroucha $^{4}$ e Nildo da Silva Dias ${ }^{2}$
}

\begin{abstract}
The rational use of nutrients is of fundamental importance for obtaining high productivity of high nutritional quality. This work was developed with the aim of evaluating the quality of pepper fruit grown under different fertigation managements and different levels of nitrogen and potassium. The experimental design was of randomised blocks in a $3 \times 6$ factorial scheme with four replications. The treatments resulted from the combination of three fertigation managements $\left(\mathrm{M}_{1}\right.$-based on the rate of absorption; $\mathrm{M}_{2}$-monitoring the conductivity of the soil solution; $\mathrm{M}_{3}$-monitoring concentrations of $\mathrm{N}$ and $\mathrm{K}$ ions in the soil solution) with six levels of $\mathrm{N}$ and $\mathrm{K}\left(\mathrm{N}_{0} \mathrm{~K}_{0}, \mathrm{~N}_{50} \mathrm{~K}_{50}, \mathrm{~N}_{100} \mathrm{~K}_{100}, \mathrm{~N}_{150} \mathrm{~K}_{150}\right.$, $\mathrm{N}_{200} \mathrm{~K}_{200}$ and $\left.\mathrm{N}_{300} \mathrm{~K}_{300}\right)$ as a percentage of the recommended dosage for the crop under conventional fertigation $\left(\mathrm{M}_{1}\right)$ or hydroponics $\left(\mathrm{M}_{2}\right.$ and $\left.\mathrm{M}_{3}\right)$. Fruit quality was evaluated for the following characteristics: $\mathrm{pH}$, soluble solids, titratable acidity, vitamin $\mathrm{C}$ content and the ratio of soluble solids to titratable acidity. The different fertigation managements only affected the levels of soluble solids (SS) and titratable acidity (TA), reducing the SS and TA. The variables under study were adjusted for the levels of $\mathrm{N}$ and $\mathrm{K}$ using quadratic models.
\end{abstract}

Key words: Quality Analysis. Capsicum annuum. Fertigation. Soil solution.

\begin{abstract}
RESUMO - O uso racional de nutrientes é de fundamental importância para obtenção de alta produção e com alta qualidade nutricional. Este trabalho foi desenvolvido com o objetivo de avaliar a qualidade de frutos de pimentão cultivado sob diferentes manejos de fertirrigação e níveis de nitrogênio e potássio. Adotou-se o delineamento experimental em blocos casualizados, em esquema fatorial 3 x 6 com quatro repetições. Os tratamentos resultaram da combinação de três sistemas de manejo da fertirrigação (M1-Fertirrigação a partir da marcha de absorção; M2-Fertirrigação a partir do monitoramento da condutividade da solução do solo; M3-monitoramento da concentração de íons de N e K na solução do solo) com seis níveis de N e K (N0K0, N50K50, N100K100, N150K150, N200K200 e N300K300 (\%) da dose recomendada para a cultura sob fertirrigação convencional (M1) ou hidroponia (M2 e M3)). A qualidade dos frutos foi avaliada para as seguintes características: $\mathrm{pH}$, sólidos solúveis, acidez titulável, teor de vitamina $\mathrm{C}$ e relação sólidos solúveis/acidez titulável. Os manejos de fertirrigação afetaram apenas o teor de sólidos solúveis (SS) e a acidez titulável (AT), reduzindo os SS e AT. As variáveis estudadas foram ajustadas com modelos quadráticos para os níveis de $\mathrm{N}$ e K.
\end{abstract}

Palavras-chave: Análise de qualidade. Capsicum annuum. Fertirrigação. Solução do solo.

\footnotetext{
DOI: $10.5935 / 1806-6690.20150064$

* Autor para correspondência

${ }^{1}$ Recebido para publicação em 30/05/2012; aprovado em 26/05/2015

Parte da Tese de Doutorado do primeiro autor apresentada ao Programa de Pós-Graduação em Engenharia de Biossistemas - ESALQ/USP, pesquisa financiada pelo CNPq, Edital Universal/2009

${ }^{2}$ Departamento de Ciências Ambientais e Tecnológicas, Universidade Federal Rural do Semi-Árido, Av. Francisco Mota, 572, Bairro Costa e Silva, Mossoró-RN, Brasil, 59.625-900.thikaoamigao@ufersa.edu.br, jfmedeir@ufersa.edu.br, nildo@ufersa.edu.br

${ }_{3}^{3}$ Departamento de Engenharia de Biossistemas, ESALQ/USP, Piracicaba-SP, Brasil, snduarte@esalq.usp.br

${ }^{4}$ Departamento de Agrotecnologia e Ciências Sociais, UFERSA, Mossoró, RN, Brasil, aroucha@ufersa.edu.br
} 


\section{INTRODUCTION}

The pepper is among the ten most cultivated vegetable crops in Brazil, and is grown in all Brazilian states. The southeastern region supplies $48 \%$ of domestic production, with the State of São Paulo being the largest producer of the vegetable, having a planted area of 2,603 ha, and a total production in 2011 of 230,040 Mg (IEA, 2012).

Among the environmental factors that influence productivity and quality in the crop, irrigation and fertilisation deserve more attention as they display greater levels of crop response. Proper management of these factors is therefore of fundamental importance in obtaining products of high quality. Potassium and nitrogen are the nutrients which are most exported by pepper plants (EPSTEIN; BLOOM, 2006; FONTES; DIAS; GRAÇA, 2005; MARCUSSI; GODOY; VILLAS BÔAS, 2004), so that high rates of these elements when applied as coverage improve the efficiency of fertilisation, decreasing loss by seepage and evaporation.

In addition to the amount of nutrients to be applied, another factor of primary importance is related to how and when they are supplied to the plants. According to Fontes, Dias and Graça (2005), it is necessary to define how much to apply with each fertigation, in order to meet the needs of the plant, since a reduction in production of the pepper in response to increased rates of nitrogen fertiliser has been linked to the effects caused by an increase in electrical conductivity of the nutrient solution.

Traditionally, fertigation management has been carried out by means of predetermined quantities of fertiliser, divided according to the rate of absorption of the crop, with usually no monitoring of the concentration of ions in the soil solution or the nutritional status of the plant, in some cases resulting in excessive costs for fertiliser and in others, salinisation of the soil.

The excessive use of fertilisers can cause physiological disorders, such as a fall in production and in fruit quality, nutritional imbalance and an increase in osmotic pressure. Excess potassium in the soil solution can negatively affect the absorption of $\mathrm{Ca}^{2+}$ and $\mathrm{Mg}^{2+}$ by the plants, due to the antagonistic effect of the $\mathrm{K}^{+}$ion (EPSTEIN; BLOOM, 2006).

In order to avoid the possible accumulation of salts in the soil and an excess of toxic ions, research has been developed, with an emphasis on monitoring the soil solution using extractors equipped with porous capsules. In this line of research, some authors have studied the application of this technology to monitoring electrical conductivity and controlling soil salinity in a protected environment (BLANCO; FOLEGATTI; HENRIQUES NETO, 2008;
ELOI; DUARTE; SOARES, 2007; MEDEIROS et al., 2010), while other researchers have used the technology to monitor the concentration of specific ions such as $\mathrm{N}$ and $\mathrm{K}$ in the soil solution (SILVA JÚNIOR et al., 2010; TAVARES, 2005), with satisfactory results being found in both cases.

Although satisfactory results have been found, there is still a difference between these methods, and as yet no studies comparing the two methodologies. It is therefore necessary to assess the effect of each methodology on the plants. Given the above, the aim of this work was to evaluate the quality of pepper fruit cultivated under different fertigation managements and levels of nitrogen and potassium.

\section{MATERIAL AND METHODS}

The experiment was conducted at the Department of Environmental Science and Technology, on the campus of the Federal Rural University of the Semi-Arid, UFERSA, in Natal, in the State of Rio Grande do Norte (RN), Brazil ( $5^{\circ} 11^{\prime} \mathrm{S}$ and $37^{\circ} 20^{\prime} \mathrm{W}$, at an altitude of $18 \mathrm{~m}$ ), with an average annual temperature of $27.4{ }^{\circ} \mathrm{C}$, relative humidity of $68.9 \%$, and rainfall of $673.9 \mathrm{~mm}$, being fairly irregular and concentrated in the first months of the year. According to the Köppen classification, the climate is of type BSwh', i.e. hot and dry, with a rainy season going into the autumn.

The work was carried out in two stages, the first under laboratory conditions and the second in a protected environment; in both stages, the material used was from a dystrophic Red-Yellow Argisol (SBCS), collected from the 0.0 to $0.20 \mathrm{~m}$ layer of an as-yet uncultivated area, located on the Rafael Fernandes Experimental Farm of UFERSA. Subsamples of soil were taken and analysed for their chemical and physical characteristics (EMBRAPA, 1997). The results are shown in Table 1.

The first stage consisted in calibrating the extractors to be used in monitoring the soil solution; the calibration being carried out according to the methodology used by Oliveira et al. (2011). Table 2 shows the equations obtained from the calibration, for correlating the concentrations of $\mathrm{NO}_{3-}, \mathrm{K}^{+}$and the electrical conductivity of the solutions applied to the soil samples, together with their respective concentrations in the solution collected with the extractors and used in the second stage of the experiment on the pepper crop.

The second stage of the experiment was conducted in a greenhouse. A randomised block design was used in a $3 \times 6$ factorial, giving 18 treatments with four replications, each experimental unit consisting of one pot with a capacity of $25 \mathrm{~L}$, and one plant per pot. 
Table 1 - Physiochemical characteristics of the soil material used in the experiment

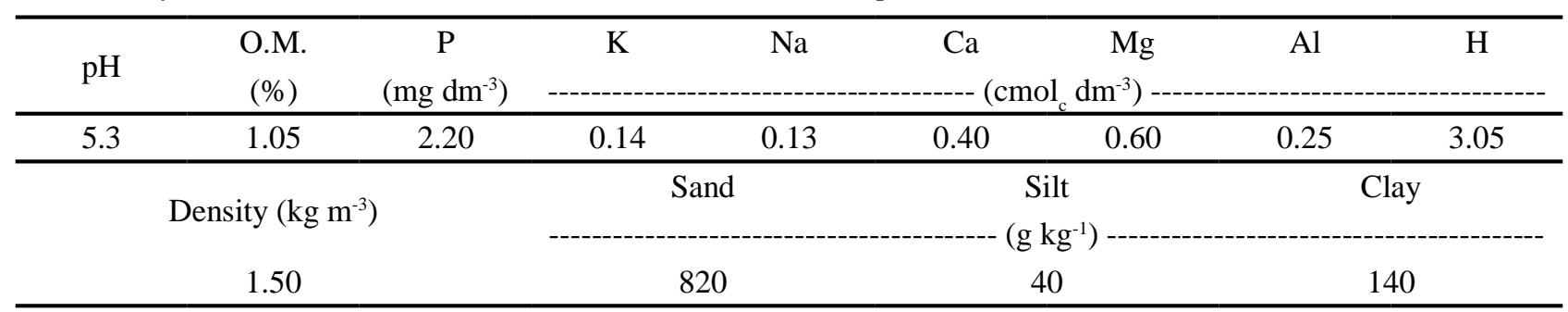

Table 2 - Regression equations obtained in calibrating the soil solution extractors

\begin{tabular}{lcc}
\hline \multicolumn{1}{c}{ Variable } & Equation & $\mathrm{R} 2$ \\
\hline Potassium & $* \mathrm{~K}_{\mathrm{Col}}=1.034 \mathrm{~K}_{\mathrm{apl}}-7.966$ & 0.983 \\
Nitrogen & $\mathrm{N}_{\mathrm{Col}}=0.905 \mathrm{~N}_{\mathrm{apl}}-22.15$ & 0.984 \\
Electrical conductivity & $\mathrm{CE}_{\mathrm{Col}}=0.831 \mathrm{CE}_{\mathrm{abl}}+0.483$ & 0.966 \\
\hline
\end{tabular}

${ }^{*} \mathrm{~K}_{\mathrm{col}}$ - Potassium concentration of the solution collected in the extrators; $\mathrm{K}_{\mathrm{apl}}$ - Potassium concentration of the applied solution; $* \mathrm{~N}_{\mathrm{col}}-\mathrm{Nitrogen}$ concentration of the solution collected in the extrators; $\mathrm{N}_{\mathrm{apl}}$ - Nitrogen concentration of the applied solution; $* \mathrm{CE}_{\mathrm{col}}$ - Electrical conductivity of the solution collected in the extrators; $\mathrm{CE}_{\text {apl }}$ - Electrical conductivity of the applied solution

The treatments consisted of a combination of fertigation managements $\left(\mathrm{M}_{1}\right.$-Fertigation from the rate of absorption recommended by Fontes, Dias and Graça (2005); $M_{2}$-Fertigation from monitoring the conductivity of the soil solution; $\mathrm{M}_{3}$-Fertigation from monitoring the concentration of $\mathrm{N}$ and $\mathrm{K}$ ions in the soil solution); with five levels of $\mathrm{N}$ and $\mathrm{K}\left(\mathrm{N}_{0} \mathrm{~K}_{0}, \mathrm{~N}_{50} \mathrm{~K}_{50}, \mathrm{~N}_{100} \mathrm{~K}_{100}, \mathrm{~N}_{150} \mathrm{~K}_{150}\right.$, $\mathrm{N}_{200} \mathrm{~K}_{200}$ e $\mathrm{N}_{300} \mathrm{~K}_{300}(\%)$ ) of the rates for these nutrients recommended for a pepper crop in the region of Mossoró, $\mathrm{RN}$, corresponding to 215 and $314 \mathrm{~kg} \mathrm{ha}^{-1} \mathrm{~N}$ and $\mathrm{K}$ respectively (FREITAS, 2009).

In the $\mathrm{M}_{2}$ and $\mathrm{M}_{3}$ managements, six doses of $\mathrm{N}$ and $\mathrm{K}\left(\mathrm{N}_{0} \mathrm{~K}_{0}, \mathrm{~N}_{50} \mathrm{~K}_{50}, \mathrm{~N}_{100} \mathrm{~K}_{100}, \mathrm{~N}_{150} \mathrm{~K}_{150}, \mathrm{~N}_{200} \mathrm{~K}_{200}\right.$ e $\mathrm{N}_{300} \mathrm{~K}_{300}$ (\%)) were used, based on the concentrations of these nutrients in a nutrient solution recommended for a pepper crop under an NFT hydroponic system (CASTELLANE; ARAÚJO, 1994). The levels for electrical conductivity $\left(\mathrm{M}_{2}\right)$ and for $\mathrm{N}$ and $\mathrm{K}\left(\mathrm{M}_{3}\right)$ refer to the concentrations of these nutrients in the soil solution collected with the extractors. The adjustment curves obtained in the first stage were therefore used to define the levels of $\mathrm{N}$ and $\mathrm{K}$ to be used in managements $\mathrm{M}_{2}$ and $\mathrm{M}_{3}$, with levels being defined for electrical conductivity $(0.6,1.6,22 ; 3.1 ; 3.8$ and 4.4, $\left.\mathrm{dS} \mathrm{m} \mathrm{m}^{-1}\right)$ and $\mathrm{N}$ and $\mathrm{K}\left(\mathrm{N}_{0} \mathrm{~K}_{0}, \mathrm{~N}_{76} \mathrm{~K}_{123}, \mathrm{~N}_{152} \mathrm{~K}_{245}\right.$, $\mathrm{N}_{228} \mathrm{~K}_{368}, \mathrm{~N}_{304} \mathrm{~K}_{490}$ e $\mathrm{N}_{380} \mathrm{~K}_{613}, \mathrm{mg} \mathrm{L}^{-1}$ ).

The pepper crop (Capsicum annuum) used was the hybrid 'Atlantis' (Topseed®), chosen for being one of the most cultivated in the region. The seedlings used were 35 days old and came from a specialist company in the area. They were transplanted into plastic pots with a capacity of $25 \mathrm{~L}$, using the same type of soil as used in the first stage.

A tensiometer and a solution extractor were installed in each pot, both at a depth of $15 \mathrm{~cm}$, the first to monitor the humidity and determine the amount of water to be applied at each irrigation, and the second to collect and monitor the soil solution. Solutions with an ion concentration in accordance with the results obtained in the first stage were then applied, in a volume sufficient to wet the soil to a moisture content relative to the maximum water retention capacity.

Fertiliser was applied to the surface by fertigation throughout the crop cycle. For the $M_{1}$ management, fertigation was carried out every four days according to the rate of absorption of the crop (FONTES; DIAS; GRAÇA, 2005). For the $M_{2}$ and $M_{3}$ managements, fertigation was carried out according to analysis of the solutions collected with the extractors, which were obtained using the same procedure as in the first stage. In order to determine when, and the amount of nutrients to be applied in the treatments under $\mathrm{M}_{2}$ and $\mathrm{M}_{3}$, a $20 \%$ range of variation in electrical conductivity and in the concentrations of $\mathrm{NO}_{3}$ and $\mathrm{K}^{+}$was adopted as a decision parameter, above which replacement of nutrients was carried out by fertigation.

Irrigation management was by puncture tensiometer, monitored daily, and based on the characteristic soil water retention curve (Figure 1). Immediately after each collection of soil solution, the tension was verified in order to obtain the current soil moisture content and correct the ion concentration 
for when the soil is at field capacity, following a methodology used by Silva Júnior et al. (2010).

Figure 1 - Characteristic soil water retention curve

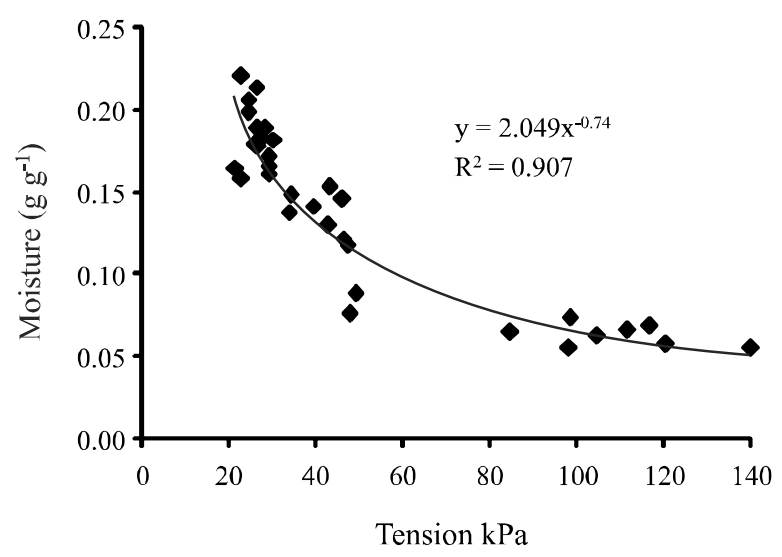

The volume of solution applied with each fertigation event was enough to raise the current soil moisture content to field capacity. Fertigation was done manually, using a graduated test tube and beaker to measure the volume of solution; when it was not necessary to apply fertiliser, only water was applied through the irrigation system. For treatments containing no nitrogen or potassium $\left(\mathrm{N}_{0} \mathrm{~K}_{0}\right)$, the other nutrients were applied in order to obtain the plant response only to changes in the levels of $\mathrm{N}$ and $\mathrm{K}$. The following fertilisers were used as nutrient sources: calcium nitrate, potassium chloride, potassium phosphate monobasic, potassium nitrate, sodium nitrate, calcium chloride, magnesium sulphate and phosphoric acid. The amounts of $\mathrm{N}$ and $\mathrm{K}$ applied during the experiment for each fertigation management, and the levels of $\mathrm{N}$ and $\mathrm{K}$, are shown in Table 3 .
Six collections were made, with the fourth being chosen to carry out quality analysis, as it was possible to harvest fruit from all the plants. From each treatment, five fruits were randomly selected from each plant (replication), the fruits, packed in plastic bags, were then transported to the Postharvest Laboratory for Fruits and Vegetables of UFERSA. Before being analysed, the fruits were washed with deionized water, dried and left to dry out at room temperature.

Titratable acidity was determined by the titration of $10 \mathrm{~g}$ of pulp ground in a blender and homogenised with 50 $\mathrm{mL}$ of distilled water. A standard solution of $0.10 \mathrm{~N} \mathrm{NaOH}$ was used as titrant. The results were expressed in grams of citric acid per $100 \mathrm{~g}$ of sample. The $\mathrm{pH}$ was obtained with the use of a digital $\mathrm{pH}$ meter. The soluble solid content was determined using a refractometer; the reading being taken with a small sample of ground pulp placed on the prism, with the results expressed in ${ }^{\circ}$ Brix. The vitamin $\mathrm{C}$ content was determined by titration with DFI, and the result expressed in mg of ascorbic acid per $100 \mathrm{~g}$ of pulp.

The resulting data were submitted to variance analysis applying the F-test, using the Sisvar statistical software (FERREIRA, 2008). For variables showing a significant response, the data were fitted to regression equations, adopting the mathematical model that gave the highest degree of significance and the highest coefficient of determination $\left(\mathrm{R}^{2}\right)$. Average values relating to fertigation management were compared using Tukey's test at 5\% probability.

\section{RESULTS AND DISCUSSION}

From the variance analysis, the effect of a significant interaction can be seen between the systems of fertigation management $(\mathrm{M})$ and levels of $\mathrm{N}$ and $\mathrm{K}(\mathrm{L})$, only for the variables, soluble solids (SS) and vitamin C content (Vit

Table 3 - Accumulated amount, and nitrogen and potassium applied during the experiment

\begin{tabular}{|c|c|c|c|c|c|c|}
\hline \multirow{3}{*}{ Level of NK (\%) } & \multicolumn{2}{|c|}{$\mathrm{M}_{1}$} & \multicolumn{2}{|c|}{$\mathrm{M}_{2}$} & \multicolumn{2}{|c|}{$\mathrm{M}_{3}$} \\
\hline & $\mathrm{N}$ & $\mathrm{K}$ & $\mathrm{N}$ & $\mathrm{K}$ & $\mathrm{N}$ & $\mathrm{K}$ \\
\hline & \multicolumn{2}{|c|}{$\left(\right.$ g plant $\left.^{-1}\right)$} & \multicolumn{2}{|c|}{$\left(\right.$ g plant $\left.^{-1}\right)$} & \multicolumn{2}{|c|}{$\left(\right.$ g plant $\left.^{-1}\right)$} \\
\hline 0 & 0.00 & 0.00 & 0.00 & 0.00 & 0.00 & 0.00 \\
\hline 50 & 6.00 & 6.65 & 3.26 & 8.95 & 4.06 & 6.31 \\
\hline 100 & 11.65 & 13.29 & 6.58 & 11.59 & 6.68 & 10.41 \\
\hline 150 & 17.47 & 19.55 & 10.11 & 16.38 & 8.39 & 12.92 \\
\hline 200 & 23.33 & 26.59 & 13.88 & 22.10 & 11.96 & 19.00 \\
\hline 300 & 29.16 & 33.24 & 21.68 & 29.27 & 12.22 & 19.14 \\
\hline
\end{tabular}

$* \mathrm{M}_{1}$ - Fertigation from rate of absorption of the crop; $\mathrm{M}_{2}-$ Fertigation from monitoring the concentration of $\mathrm{N}$ and $\mathrm{K}$ ions in the soil solution; $\mathrm{M}_{3}$ Fertigation from monitoring the electrical conductivity of the soil solution 
C), at $1 \%$ probability; no effect from the interaction was seen for $\mathrm{pH}$, titratable acidity (TA) and the SS/TA ratio $(\mathrm{p}>0.05)$. There was an isolated effect from fertigation management for SS and AT $(\mathrm{p}<0.01)$, being not significant for the other variables ( $p>0.05$ ), whereas for the isolated effect of the levels of NK, there was a significant response for all the studied variables $(\mathrm{p}<0.01)$, as shown in Table 4.

There was no significant difference from the systems of fertigation management on $\mathrm{pH}$, TA or $\mathrm{SS} /$ TA, with mean values of $6.14(\mathrm{pH}), 0.33$ (AT) and 12.68 (SS/TA) being obtained between fertigation managements, as shown in Table 5.

The presence of an interaction between management and levels of $\mathrm{N}$ and $\mathrm{K}$ for the characteristic SS, shows the dependence of the two factors, and requires further study by breakdown of the levels of one factor as a function of the levels of the second factor. On the other hand, a lack of interaction allows the two factors to be studied independently.
After a breakdown of the factors being studied (fertigation managements and levels of $\mathrm{N}$ and $\mathrm{K}$ ), a significant difference is seen between managements only for the levels $\mathrm{N}_{100} \mathrm{~K}_{100}, \mathrm{~N}_{200} \mathrm{~K}_{200}$ and $\mathrm{N}_{300} \mathrm{~K}_{300}$; the highest values being obtained with management $\mathrm{M}_{1}$ for $\mathrm{N}_{100} \mathrm{~K}_{100}$, with $\mathrm{M}_{2}$ and $\mathrm{M}_{3}$ for $\mathrm{N}_{200} \mathrm{~K}_{200}$, and with $\mathrm{M}_{1}$ and $\mathrm{M}_{3}$ for $\mathrm{N}_{300} \mathrm{~K}_{300}$ (Table 5).

Despite soluble solids not having great in importance when marketing the pepper, as in the industrial tomato (EMBRAPA, 2006), they affect the taste of the pepper (ROCHA et al., 2006). It can be seen that the level of $\mathrm{N}_{100} \mathrm{~K}_{100}$, resulted in good results for SS with $M_{1}$. Chitarra and Chitarra (2005) argue that nutritional balance in the plants is important for obtaining quality fruit; they emphasize that nitrogen performs the function of protein synthesis, and potassium acts in the transportation of carbohydrates and plays an important role in the size, shape, colour and flavour of the fruit.

Table 4 - Summary of the variance analysis for $\mathrm{pH}$, soluble solids (SS), titratable acidity (TA), vitamin C (Vit C) and SS/TA ratio, in pepper fruit cultivated in a greenhouse, under different systems of fertigation management and levels of nitrogen and potassium

\begin{tabular}{|c|c|c|c|c|c|}
\hline \multirow{2}{*}{$\begin{array}{c}\text { Source of } \\
\text { variation }\end{array}$} & \multicolumn{5}{|c|}{ 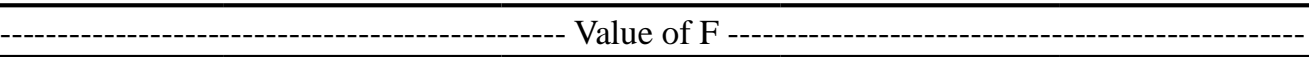 } \\
\hline & $\mathrm{pH}$ & SS & TA & Vit C & SS/AT \\
\hline Management (M) & $0.34^{\mathrm{ns}}$ & $10.43 * *$ & $6.22 * *$ & $2.02^{\mathrm{ns}}$ & $1.78^{\mathrm{ns}}$ \\
\hline Level $(\mathrm{N})$ & $26.38 * *$ & $15.02 * *$ & $34.40 * *$ & $68.78 * *$ & $14.89 * *$ \\
\hline Mx L & $1.95^{\mathrm{ns}}$ & $3.79 * *$ & $1.85^{\mathrm{ns}}$ & $4.95 * *$ & $1.84^{\mathrm{ns}}$ \\
\hline Blocks & 1.56 & 1.91 & 4.46 & 0.73 & 3.43 \\
\hline $\mathrm{CV}(\%)$ & 2.87 & 4.56 & 8.92 & 14.43 & 10.36 \\
\hline
\end{tabular}

${ }_{\text {ns }}$ and $* *$ - Not significant and significant at $1 \%$ probability respectively

Table 5 - Mean values for quality parameters, in pepper fruit cultivated in a greenhouse, under different systems of fertigation management and levels of nitrogen and potassium

\begin{tabular}{|c|c|c|c|c|c|c|}
\hline \multirow{3}{*}{ Level of NK (\%) } & \multirow{3}{*}{ Management } & \multirow{3}{*}{$\mathrm{pH}$} & \multicolumn{4}{|c|}{ Variable ------------------------- } \\
\hline & & & SS & TA & Vit C & \\
\hline & & & ${ }^{\circ}$ Brix & (\% acid $100 \mathrm{~mL}^{-1}$ sample $)$ & $\left(\mathrm{mg} 100 \mathrm{~g}^{-1}\right)$ & SS/TA \\
\hline \multirow{3}{*}{0} & $\mathrm{M}_{1}$ & 5.6 & $3.7 \mathrm{~A}$ & 0.3 & $157.3 \mathrm{~A}$ & 14.7 \\
\hline & $\mathrm{M}_{2}$ & 5.6 & $3.7 \mathrm{~A}$ & 0.3 & $157.3 \mathrm{~A}$ & 14.7 \\
\hline & $\mathrm{M}_{3}$ & 5.6 & $3.7 \mathrm{~A}$ & 0.3 & $157.3 \mathrm{~A}$ & 14.7 \\
\hline \multirow{3}{*}{50} & $\overline{M_{1}}$ & 6.3 & $4.1 \mathrm{~A}$ & 0.3 & $69.0 \mathrm{~B}$ & 12.8 \\
\hline & $\mathrm{M}_{2}$ & 6.2 & $3.9 \mathrm{~A}$ & 0.3 & $85.6 \mathrm{AB}$ & 14.5 \\
\hline & $\mathrm{M}_{3}$ & 6.2 & $3.9 \mathrm{~A}$ & 0.3 & $99.4 \mathrm{~A}$ & 13.0 \\
\hline \multirow{3}{*}{100} & $\mathrm{M}_{1}$ & 6.3 & $4.7 \mathrm{~A}$ & 0.3 & $55.2 \mathrm{~A}$ & 14.1 \\
\hline & $\mathrm{M}_{2}$ & 6.2 & $3.9 \mathrm{~B}$ & 0.4 & $69.0 \mathrm{~A}$ & 11.6 \\
\hline & $\mathrm{M}_{3}$ & 6.2 & $4.2 \mathrm{~B}$ & 0.4 & $69.0 \mathrm{~A}$ & 11.3 \\
\hline
\end{tabular}


Table 5 Continued

\begin{tabular}{cllllll}
\hline \multirow{3}{*}{150} & $\mathrm{M}_{1}$ & 6.3 & $4.2 \mathrm{~A}$ & 0.4 & $96.6 \mathrm{~A}$ & 10.4 \\
& $\mathrm{M}_{2}$ & 6.1 & $4.1 \mathrm{~A}$ & 0.4 & $91.1 \mathrm{~A}$ & 11.0 \\
& $\mathrm{M}_{3}$ & 6.3 & $4.0 \mathrm{~A}$ & 0.4 & $63.5 \mathrm{~B}$ & 11.3 \\
\hline \multirow{3}{*}{200} & $\mathrm{M}^{1}$ & 6.4 & $4.1 \mathrm{~B}$ & 0.4 & $107.6 \mathrm{~A}$ & 10.5 \\
& $\mathrm{M}^{2}$ & 6.4 & $4.1 \mathrm{~A}$ & 0.3 & $69.0 \mathrm{~B}$ & 12.4 \\
& $\mathrm{M}^{3}$ & 6.1 & $4.4 \mathrm{~A}$ & 0.4 & $80.0 \mathrm{~B}$ & 10.9 \\
\hline \multirow{3}{*}{300} & $\mathrm{M}_{1}$ & 6.0 & $4.4 \mathrm{~A}$ & 0.3 & $102.1 \mathrm{~A}$ & 13.7 \\
& $\mathrm{M}_{2}$ & 6.3 & $3.9 \mathrm{~B}$ & 0.3 & $80.0 \mathrm{AB}$ & 13.6 \\
& $\mathrm{M}_{3}$ & 6.3 & $4.1 \mathrm{AB}$ & 0.3 & $74.5 \mathrm{~B}$ & 13.2 \\
\hline \multirow{3}{*}{ Mean } & $\mathrm{M}_{1}$ & $6.1 \mathrm{~A}$ & 4.2 & $0.3 \mathrm{~A}$ & 98.0 & $12.7 \mathrm{~A}$ \\
& $\mathrm{M}_{2}$ & $6.2 \mathrm{~A}$ & 3.9 & $0.3 \mathrm{~A}$ & 92.0 & $12.9 \mathrm{~A}$ \\
& $\mathrm{M}_{3}$ & $6.1 \mathrm{~A}$ & 4.1 & $0.3 \mathrm{~A}$ & 90.6 & $12.4 \mathrm{~A}$ \\
\hline
\end{tabular}

$* \mathrm{M}_{1}$ - Fertigation from the rate of absorption of the crop; $\mathrm{M}_{2}$ - Fertigation from monitoring the concentration of $\mathrm{N}$ and $\mathrm{K}$ ions in the soil solution; $\mathrm{M}_{3}$ - Fertigation from monitoring the electrical conductivity of the soil solution. **Mean values followed by the same letter do not differ statistically by Tukey's test at $5 \%$ probability

Freitas (2009), working in the field with the same genetic material used in this experiment, found mean values of $4.80^{\circ}$ Brix for SS. These values are very close to those found in this study, which shows that in a protected environment, the plants produce fruit with characteristics similar to under field conditions.

In a breakdown of the levels of $\mathrm{N}$ and $\mathrm{K}$ by management, it was seen that with managements $M_{1}$ and $\mathrm{M}_{3}$, the highest values were estimated at 4.4 and $4.3^{\circ} \mathrm{Brix}$ for concentrations corresponding to 175 and $250 \%$ of $\mathrm{NK}$, resulting in a percentage increase of 16.3 and $16.9 \%$ respectively, compared to the treatment without $\mathrm{NK}$, in which an SS of $3.7^{\circ}$ Brix was obtained (Figure 2A). With management $\mathrm{M}_{2}$, the greatest value was estimated for the NK concentration of $150 \%$, with a maximum value of 3.9 ${ }^{\circ}$ Brix and an increase of $6.1 \%$ compared to the absence of NK. The results obtained in this study are below those found by Factor, Araújo and Villela Júnior (2008), who found an SS of around $7{ }^{\circ}$ Brix, but very close to the values found by Charlo et al. (2009) in other pepper hybrids (5.8 to $7.4^{\circ}$ Brix).

Although it is not possible to distinguish the effect of each nutrient ( $\mathrm{N}$ and $\mathrm{K}$ ) on the $\mathrm{SS}$ in the fruit pulp, the observed increase can be attributed to the direct participation of $\mathrm{K}$ in the soil solution, since the effect of $\mathrm{N}$ on the variable is rarely seen, as in results obtained with the watermelon (ANDRADE JÚNIOR et al., 2006) and the melon (QUEIROGA et al., 2011). Silva Júnior et al. (2010), working with a melon crop under different levels of $\mathrm{N}$ and $\mathrm{K}$ in the soil solution $\left(\mathrm{M}_{1}\right)$, obtained a negative response to increases in the concentration of $\mathrm{N}$, and a positive response for $\mathrm{K}$.
Thus, the increase in SS in response to increases in the levels of NK, may be attributed to the indirect effect of $\mathrm{N}$, as this promotes greater leaf development, and therefore more photosynthetic activity in the plants, since $\mathrm{N}$ is the nutrient that most affects growth of the leaf area and the rate of photosynthesis in the crop (PONS; WESTBEEK, 2004).

It is known that SS levels are influenced by the water content of the fruit, in such a way that the lower the water content, the higher the concentration of soluble solids, thus with the increasing concentration of nutrients in the soil solution, there is a reduction in the osmotic potential of the solution, which hampers the absorption of water by the plants, and since the fruit is the part of the plant with the highest water content, it is there that the greatest reduction of moisture takes place, increasing the concentration of solutes.

For the rate of $\mathrm{N}_{50} \mathrm{~K}_{50}$, the highest value was seen with management $M_{3}$, and the lowest with $M_{1}$. Management $M_{2}$ did not differ among the other irrigation managements. Management $\mathrm{M}_{3}$ had the lowest values for $\mathrm{N}_{150} \mathrm{~K}_{150}, \mathrm{~N}_{200} \mathrm{~K}_{200}$ and $\mathrm{N}_{300} \mathrm{~K}_{300}$, despite there being no difference between this management and $\mathrm{M}_{2}$ for the last two levels (Table 5). Nonetheless, concentrations of Vit C, still remained at satisfactory levels. When planting peppers employing different spacing, Freitas (2009) found that there was no effect from treatment on the characteristic Vit C, with levels between 33.14 and 36.4 mg AA $100 \mathrm{~g}^{-1}$.

There was significant response to levels of NK for the characteristic Vit $\mathrm{C}$, however the response was varied and depended on the type of management used, 
Figure 2 - Soluble solids (A), Vitamin C (B), pH (C), titratable acidity (D), SS/TA ratio (E), in the pulp of pepper fruit, for different fertigation managements and levels of NK in the soil solution

- Management 1

Danagement 2

Management 3
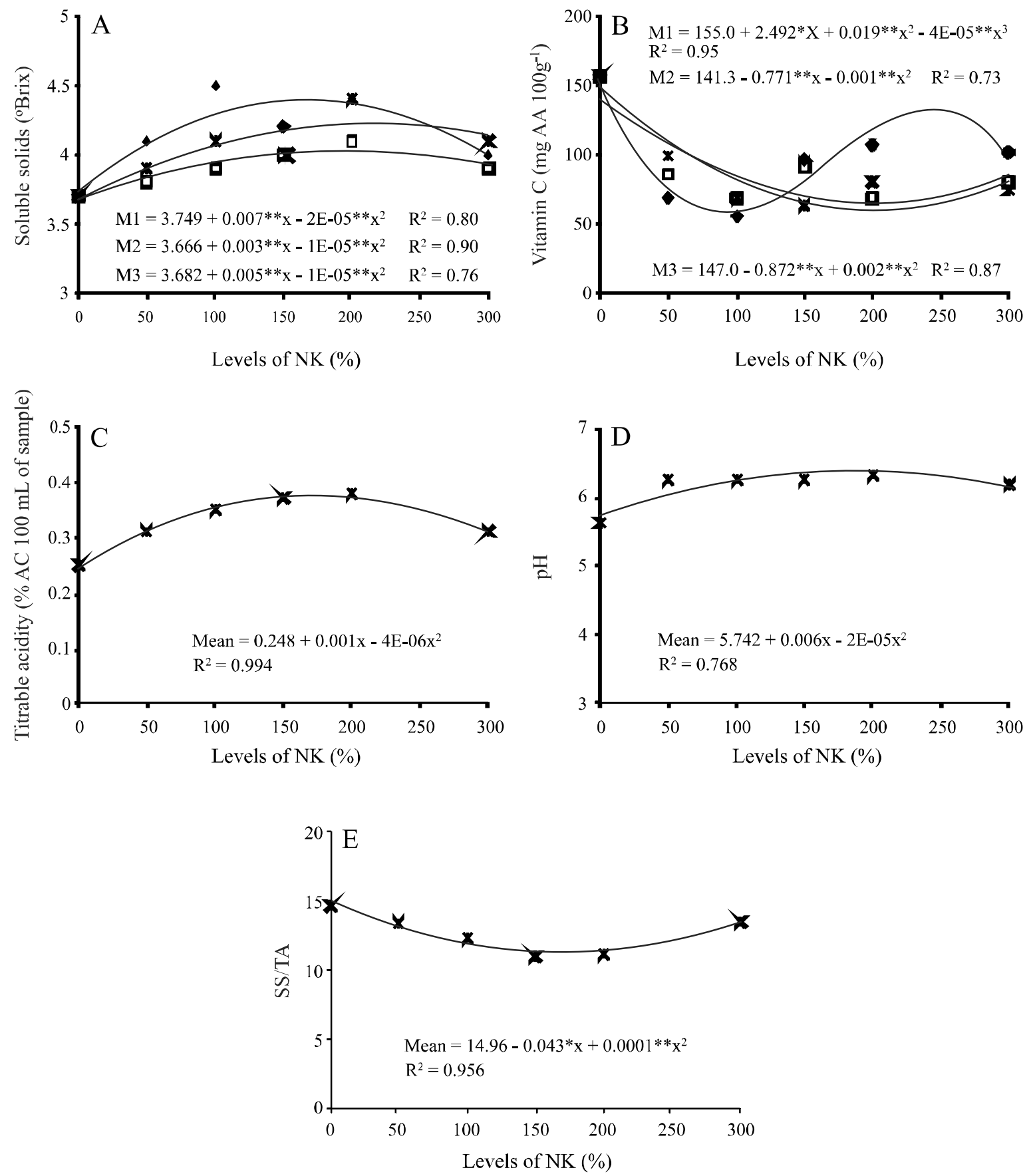

with the data being fitted to quadratic equations for managements $\mathrm{M}_{2}$ and $\mathrm{M}_{3}$, where the greatest values were obtained without application of NK (141.3 mg and 147 $100 \mathrm{~g}^{-1}$ respectively), and the lowest values obtained at the highest concentrations of NK. For $\mathrm{M}_{1}$ the data was fitted to the cubic model, decreasing until an NK ratio of
$100 \%$, and then increasing from there, followed by further reduction (Figure 2B). Indeed, from the results observed in this study, it was not expected that the levels of $\mathrm{N}$ and $\mathrm{K}$ would influence the synthesis of Vit $\mathrm{C}$, regardless of management. On the other hand, it is known that the biosynthesis of ascorbic acid in plants is a process that 
is not fully understood, and has as supposed precursors, mannose and galactose (KOBLITZ et al., 2010).

There was no effect from management on the $\mathrm{pH}$ of the pepper (Table 5). Similarly, Eloi et al. (2011) and Medeiros (2010) found no difference in the $\mathrm{pH}$ of the fruit pulp when a tomato crop was grown in a greenhouse, employing the same fertigation managements $\left(\mathrm{M}_{1}\right.$ and $\left.\mathrm{M}_{3}\right)$ used in this work. A fact also reported by Medeiros et al. (2010) in a cucumber crop.

As there was no significant interaction for $\mathrm{pH}$ between the factors being studied, a simple regression equation was adjusted for the three systems of fertigation management, with the mean data being fitted to the second-degree polynomial model. The greatest value for $\mathrm{pH}$ was estimated for the level $\mathrm{N}_{150} \mathrm{~N}_{150}$, giving a $\mathrm{pH}$ of 6.19 , regardless of fertigation management, corresponding to a percentage increase of $7.84 \%$ relative to the treatment with no application of $\mathrm{N}$ and $\mathrm{K}\left(\mathrm{N}_{0} \mathrm{~N}_{0}\right)$ (Figure $2 \mathrm{C}$ ), for which the lowest $\mathrm{pH}$ of 5.61 was found.

Factor, Villela Júnior and Araújo (2008) working with the hybrid 'Margarita' under different nutrient solutions, found no significant difference from the solutions for the $\mathrm{pH}$ of pepper pulp. Macedo and Alvarenga (2005), studying potassium fertigation in a tomato crop, had no response for the different rates of $\mathrm{K}$, differing from the results obtained in the present work; moreover, as can be seen in Figure 2A, there was virtually no difference for the treatments that received potassium fertiliser. Rubio et al. (2010) also found little variation in $\mathrm{pH}$ in pepper pulp fertilised with different rates of $\mathrm{K}$.

It was found that fruit from plants without NK showed less titratable acidity (Table 5), while the highest values were detected for the rates $\mathrm{N}_{100} \mathrm{~K}_{100}, \mathrm{~N}_{150} \mathrm{~K}_{150} \mathrm{e}$ $\mathrm{N}_{200} \mathrm{~K}_{200}$. This result demonstrates that the synthesis of organic acids in the pepper pulp is influenced in some way by low (no NK and $\mathrm{N}_{50} \mathrm{~K}_{50}$ ) and high (N300K300) rates of NK. In a melon crop, Fogaça et al. (2007) found a response to TA, with behaviour similar to that obtained in this work, initially presenting a positive response and decreasing with the greater concentrations of $\mathrm{N}$ in the nutrient solution.

According to Chitarra and Chitarra (2005), in most fruits, titratable acidity is a major component of flavour as its acceptance depends on the balance between acids and sugars.

For titratable acidity (TA), a quadratic regression equation was adjusted for the three fertigation managements under study, from which was estimated the highest value for TA at the $125 \%$ concentration of NK (0.31), with a percentage increase of $25.2 \%$ being seen compared to fruits harvested from plants that did not receive $\mathrm{N}$ and $\mathrm{K}$ fertilisation (Figure 2D). Tavares (2005), working with a pepper crop in a greenhouse, but using a substrate of coconut fibre, saw no response from the pepper crop to $\mathrm{N}$ and $\mathrm{K}$ levels for $\mathrm{pH}, \mathrm{SS}$ and TA. However, Medeiros et al. (2010), working with a cucumber crop, found an increasing linear response for TA to increased concentrations of salt in the soil. Macedo and Alvarenga (2005) observed an increase in TA in response to potassium levels in tomatoes.

For the SS/TA ratio, a quadratic effect was seen for the three fertigation managements. The highest SS/ TA ratio was seen in the treatment with no application of NK (14.96), and decreased with the increase of NK in the solution, up to a concentration of $215 \% \mathrm{NK}$, when an SS/TA of 10.3 was obtained, resulting in a decrease of $30.9 \%$ (Figure 2E). This behaviour is due to the increase in NK application having increased in a similar way for SS and AT.

Unlike the orange $(\mathrm{SS} / \mathrm{TA}=11)$ and tomato $(\mathrm{SS} / \mathrm{TA}=10)$, for which there are quality standards established for the balance between soluble solids and citric acid (SS/TA), there are none established for the pepper. However, it is known that this is an important parameter for measuring the perception of taste by consumers. According to Grierson and Kader (1986), the higher the sugar and acid content, the better the flavour of the fruit.

The smallest SS/TA ratio seen with the $\mathrm{N}_{150} \mathrm{~K}_{150}$ treatment was higher than that detected by Rocha et al. (2006), who observed a higher SS/TA ratio (7.39) for the pepper hybrid 'Magali R', while Wuzhong (2002) noted a reduction in the SS/TA ratio in the tomato with increasing rates of $\mathrm{K}$.

\section{CONCLUSIONS}

1. The quality of the pepper was influenced more by the levels of nitrogen and potassium than by fertigation management;

2. The highest values for the quality parameters of the fruit were obtained at levels from $\mathrm{N}_{150} \mathrm{~K}_{150}$ to $\mathrm{N}_{200} \mathrm{~K}_{200}$ of the recommended concentration for the crop;

3. The vitamin $\mathrm{C}$ content was reduced with the increase in nitrogen and potassium fertilisation.

\section{ACKNOWLEDGEMENTS}

The authors wish to thank the National Council of Scientific and Technological Development (CNPq) for the financial aid to carry out the research, and CAPES 
for the doctoral fellowship awarded to the lead author. Thanks are also due to the Federal Rural University of the Semi-Arid (UFERSA), for access to the infrastructure necessary to the development of the experiment.

\section{REFERENCES}

ANDRADE JÚNIOR, A. S. et al. Produção e qualidade de frutos de melancia à aplicação de nitrogênio via fertirrigação. Revista Brasileira de Engenharia Agrícola e Ambiental, v. 10 , n. 4 , p. $836-841.2006$.

BLANCO, F. F.; FOLEGATTI, M. V.; HENRIQUES NETO, D. Doses de $\mathrm{N}$ e $\mathrm{K}$ no tomateiro sob estresse salino: I. Concentração de nutrientes no solo e na planta. Revista Brasileira de Engenharia Agrícola e Ambiental, v. 12, n. 1, p. 26-33, 2008.

CASTEllane, P. D.; ARAúJO, J. A. C. Cultivo sem solo: hidroponia. Jaboticabal: FUNEP, 1994. 43p.

CHARLO, H. C. O. et al. Cultivo de híbridos de pimentão amarelo em fibra da casca de coco. Horticultura Brasileira, v. 27, n. 2 , p. $155-159,2009$.

CHITARRA, M. I. F.; CHITARRA, A. B. Pós-colheita de frutos e hortaliças: fisiologia e manuseio. Lavras: UFLA, 2005. 783 p.

ELOI, M. W.; DUARTE, N. S.; SOARES, M. T. Níveis de salinidade e manejo da fertirrigação sobre características do tomateiro cultivado em ambiente protegido. Revista Brasileira Ciências Agrárias, v. 2, n. 1, p. 83-89, 2007.

ELOI, W. M. et al. Influência de diferentes níveis de salinidade nas características sensoriais do tomate. Revista Brasileira de Engenharia Agrícola e Ambiental, v. 15, n. 1, p. 16-21, 2011.

EMPRESA BRASILEIRA DE PESQUISA AGROPECUÁRIA. Sistema de produção: cultivo de tomate para industrialização. 2006. Disponível em: http://sistemaproducao.cnptia.embrapa. br/FontesHTML/Tomate/TomateIndustrial/.htm2006>. Acesso em: 22 ago. 2009.

EMPRESA BRASILEIRA DE PESQUISA AGROPECUÁRIA. Manual de métodos de análises de solo. 2. ed. Rio de Janeiro: Ministério da Agricultura e do Abastecimento, 1997. 212 p.

EPSTEIN, E.; BLOOM, A. J. Nutrição mineral de plantas: princípios e perspectivas. 2.ed. Trad.. Londrina: Editora Planta, 2006. 392p.

FACTOR, T. L.; ARAÚJO, J. A. C.; VILELLA JÚNIOR, L. V. E. Produção de pimentão em substratos e fertirrigação com efluente de biodigestor. Revista Brasileira de Engenharia Agrícola e Ambiental, v. 12, n. 2, p. 143-149, 2008.

FERREIRA, D. F. SISVAR: um programa para análises e ensino de estatística. Revista Científica Symposium, v. 6, n. 2, p. 36-41, 2008

FOGAÇA, M. A. F. et al. Concentração de nitrogênio na solução nutritiva, na produtividade e na qualidade de frutos de melão cultivado em substrato. Ciência Rural, v. 37, n. 1, p. $72-78,2007$.
FONTES, P. C. R; DIAS, E. N.; GRAÇA, R. N. Acúmulo de nutrientes e método para estimar doses de nitrogênio e de potássio na fertirrigação do pimentão. Horticultura Brasileira, v. 23, n. 2, p. 275-280, 2005.

FREITAS, K. K. C. Produção, qualidade e acúmulo de macronutrientes em pimentão cultivado sob arranjos espaciais e espaçamentos na fileira. 2009. 110 f. Tese (Doutorado em Fitotecnia) - Universidade Federal Rural do Semi-Árido, Mossoró, 2009.

GRIERSON, D.; KADER, A. A. Fruit ripening and quality. In: ATHERTON, J. G.; RUDICH, J. (Eds). The tomato crop. A scientific basis for improvement. Londres, Chapman \& Hall, p. 241-280.

INSTITUTO DE ECONOMIA AGRÍCOLA. Banco de Dados: área e produção. 2012. Disponível em: <http://ciagri.iea.sp.gov. br/bancoiea/subjetiva.aspx?cod_sis $=1 \&$ idioma $=1>$. Acesso em: 23 mar. 2012

KOBLITZ, M. G. B. Bioquimica de alimentos: teoria e aplicações práticas. Rio de Janeiro: Guanabara Koogan. 2010. 242p.

MACÊDO, L. S.; ALVARENGA, M. A. R. Efeitos de lâminas de água e fertirrigação potássica sobre o crescimento, produção e qualidade do tomate em ambiente protegido. Ciência e Agrotecnologia, v. 29, n. 2, p. 296-304, 2005.

MARCUSSI, F. F. N.; GODOY, L. J. G.; VILLAS BÔAS, R. L. Fertirrigação nitrogenada e potássica na cultura do pimentão baseada no acúmulo de $\mathrm{N}$ e $\mathrm{K}$ pela planta. Irriga, v. 9 , n. 1 , p. $41-51,2004$

MEDEIROS, P. R. F. et al. Tolerância do pepino à salinidade em ambiente protegido: efeitos sobre propriedades físicoquímicas dos frutos. Irriga, v. 15, n. 3, p. 301-311, 2010.

MEDEIROS, P. R. F. Manejo da fertirrigação em ambiente protegido visando o controle da salinidade para a cultura do tomate em solo franco-argiloso. 2010. $85 \mathrm{f}$. Tese (Doutorado em Irrigação e Drenagem) - Escola Superior de Agricultura "Luiz de Queiroz", Universidade de São Paulo, Piracicaba, 2010.

OLIVEIRA, F. A. et al. Calibração de extratores providos de cápsula porosa para monitoramento da salinidade e da concentração de íons. Engenharia Agrícola, v. 31, n. 3, p. 520528, 2011.

PONS, T. L.; WESTBEEK, M. H. M. Analysis of differences in photosynthetic nitrogen-use efficiency between four contrasting species. Physiologia Plantarum, v. 122, n. 1, p. 68-78, 2004.

QUEIROGA, F. M. et al. Efeito de doses de nitrogênio na produção e qualidade de frutos de melão gália. Revista Verde de Agroecologia e Desenvolvimento Sustentável, v. 6, n. 1 , p. $96-100,2011$

ROCHA, M. C. et al. Características de frutos de pimentão pulverizados com produtos de ação bactericida. Horticultura Brasileira, v. 24, n. 2, p. 185-189, 2006. 
RUBIO, J. S. et al. Yield and fruit quality of sweet pepper in response to fertilisation with $\mathrm{Ca}^{2+}$ and $\mathrm{K}^{+}$. Spanish Journal of Agricultural Research, v. 8, n. 1, p. 170-177, 2010.

SILVA JÚNIOR et al. Resposta do meloeiro à fertigação controlada através de íons da solução do solo: desenvolvimento vegetativo. Revista Brasileira de Engenharia Agrícola e Ambiental, v. 14, n. 7, p. 715-722, 2010.

TAVARES, A. C. S. Manejo da fertirrigação e controle da salinidade para a cultura do pimentão (Capsicum annum) utilizando medidores de íons da solução do substrato. 2005. 101 f.. Dissertação (Mestrado em Irrigação e Drenagem) - Escola Superior de Agricultura "Luiz de Queiroz", Universidade de São Paulo, Piracicaba, 2005.

WUZHONG, N. Yield and quality of fruits of solanaceous crops as affected by potassium fertilization. Better Crops, v. 13 , n. 1, p. 6-8. 2002. 